\title{
Detecting sedimentation impacts to coral reefs resulting from dredging the Port of Miami, Florida USA
}

\author{
Margaret W Miller Corresp.. 1， Jocelyn Karazsia ${ }^{2}$, Carolyn E Groves ${ }^{1,3}$ ， Sean Griffin ${ }^{4,5}$, Tom Moore ${ }^{4}$, Pace \\ Wilber $^{6}$, Kurtis Gregg ${ }^{2,5}$ \\ ${ }^{1}$ Southeast Fisheries Science Center, NOAA-National Marine Fisheries Service, Miami, Florida, United States \\ 2 Southeast Regional Office, NOAA National Marine Fisheries Service, West Palm Beach, Florida, United States \\ 3 Rosenstiel School of Marine and Atmospheric Sciences, University of Miami, Miami, Florida, United States \\ 4 Restoration Center, NOAA National Marine Fisheries Service, St. Petersburg, Florida, United States \\ 5 Earth Resources Technology, Inc., Laurel, Maryland, United States \\ ${ }^{6}$ Southeast Regional Office, NOAA National Marine Fisheries Service, Charleston, South Carolina, United States \\ Corresponding Author: Margaret W Miller \\ Email address: margaret.w.miller@noaa.gov
}

The federal channel at Port of Miami, Florida, USA, was dredged between late 2013 and early 2015, to widen and deepen the channel. While the precise effects of the dredging on surrounding coral reefs are not well quantified, previously published remote sensing analyses, as well as agency and anecdotal reports suggest the most severe and largest area of sedimentation occurred on a coral reef feature referred to as the Inner Reef, particularly in the sector north of the channel. A regional warm-water mass bleaching event followed by a coral disease outbreak during this same time frame confounded the assessment of dredging-related impacts to coral reefs adjacent to the federal channel. Inwater field assessments conducted after the completion of dredging and a time series analysis of tagged corals photographed pre-, during, and post-dredging, are used to discern dredging-related sedimentation impacts for the Inner Reef north. Results indicate increased sediment accumulation, severe in certain times and places, and an associated biological response, including significantly greater proportion of live coral tissue loss, occurred within coral reef sites located closer to the channel. Dredging projects near valuable and sensitive habitats subject to local and global stressors require monitoring methods capable of discerning non-dredging related impacts and adaptive management to ensure predicted and unpredicted project-related impacts are quantified. Anticipated increasing frequency and intensity of warming stress also suggests that manageable- butunavoidable local stressors such as dredging should be partitioned from the warmest times of year. 
1 Detecting sedimentation impacts to coral reefs resulting from dredging the Port of Miami,

2

3

4

5

7 Pace Wilber, ${ }^{6}$ Kurtis Gregg ${ }^{2,5}$

8

9

10

11

12

13

\section{4} 15

\section{7}

\section{9}

(9)

22 Corresponding Author:

23 Margaret W. Miller ${ }^{1}$

2475 Virginia Beach Drive, Miami, Florida, 33149, USA

25 Email address: Margaret.W.Miller@noaa.gov

\section{Florida, USA} USA Email: Margaret.W.Miller@,noaa.gov Florida, USA Email: Jocelyn.Karazsia@noaa.gov USA

${ }^{5}$ Earth Resources Technology, Inc., Laurel, Maryland, USA Carolina, USA

* These two authors contributed equally

${ }^{1}$ Southeast Fisheries Science Center, NOAA-National Marine Fisheries Service, Miami, Florida,

${ }^{2}$ Southeast Regional Office, NOAA-National Marine Fisheries Service, West Palm Beach,

${ }^{3}$ Rosenstiel School of Marine and Atmospheric Sciences, University of Miami, Miami, Florida,

${ }^{4}$ Restoration Center, NOAA-National Marine Fisheries Service, St. Petersburg, Florida, USA

${ }^{6}$ Southeast Regional Office, NOAA-National Marine Fisheries Service, Charleston, South

26 


\section{Abstract}

28 The federal channel at Port of Miami, Florida, USA, was dredged between late 2013 and early 292015 to widen and deepen the channel. Due to the limited spatial extent of impact-assessment 30 monitoring associated with the project, the extent of the dredging impacts on surrounding coral reefs has not been well quantified. Previously published remote sensing analyses, as well as agency and anecdotal reports suggest the most severe and largest area of sedimentation occurred on a coral reef feature referred to as the Inner Reef, particularly in the sector north of the channel. A confounding regional warm-water mass bleaching event followed by a coral disease outbreak during this same time frame made the assessment of dredging-related impacts to coral reefs adjacent to the federal channel difficult but still feasible. The current study sought to better understand the sedimentation impacts that occurred in the coral reef environment surrounding Port of Miami, to distinguish those impacts from other regional events or disturbances, and provide supplemental information on impact assessment that will inform discussions on compensatory mitigation requirements. To this end, in-water field assessments conducted after the completion of dredging and a time series analysis of tagged corals photographed pre-, during, and post-dredging, are used to discern dredging-related sedimentation impacts for the Inner Reef north. Results indicate increased sediment accumulation, severe in certain times and places, and an associated biological response (e.g., higher prevalence of partial mortality of corals) extended up to $700 \mathrm{~m}$ from the channel, whereas project-associated monitoring was limited to $50 \mathrm{~m}$ from the channel. These results can contribute to more realistic prediction of areas of indirect effect from dredging projects needed to accurately evaluate proposed projects and design appropriate compliance monitoring. Dredging projects near valuable and sensitive habitats subject to local and global stressors require monitoring methods capable of discerning non-dredging related impacts and adaptive management to ensure predicted and unpredicted project-related impacts are quantified. Anticipated increasing frequency and intensity of seasonal warming stress also suggests that manageable- but- unavoidable local stressors such as dredging should be partitioned from such seasonal thermal stress events.

\subsection{Introduction}


57 Numerous dredging projects have resulted in widespread environmental effects on coral reef

58 communities (e.g., Dodge \& Vaisnys, 1977; Bak, 1978; Rogers, 1990; Erftemeijer et al., 2012a).

59 Coastal dredging and port construction exacerbates sediment influx by resuspending benthic

60 sediments (PIANC, 2010), and fine sediments tend to have greater effects on corals compared to

61 coarse sediments (Erftemeijer et al., 2012a). The spatial extent of impacts from dredging can be

62 variable, and in a severe case, water quality impacts have been detected up to $20 \mathrm{~km}$ away from

63 the dredging activity when oceanographic features included unidirectional flow during the

64 project (Fisher et al., 2015). Erftemeijer et al. (2012a) note poor understanding of the biological

65

66

67

68

69

70

71

72

73

74

75

76

77

78

79

80

81

82

83

84

85

response of corals to sedimentation can result in inappropriate management of dredging projects and provide several examples of dredging operations near coral reefs where inadequate management contributed to significant damage to reefs and mortality of corals. However, establishing realistic and ecologically meaningful sedimentation thresholds, as permit conditions and for use as triggers in an adaptive monitoring and management program, can be a challenge in coral reef environments (Erftemeijer et al., 2012a). To effectively minimize negative impacts on corals and coral reefs, a combination of reactive (feedback) monitoring of water quality and coral health during dredging activities and spill-budget modelling of dredging plumes could be used to guide decisions on when to modify (or even suspend) dredging (Erftemeijer et al., 2012a).

The Port of Miami entrance channel traverses coral reefs within the northern portion of the Florida Reef Tract. Six coral reef or hardbottom features characterized by Walker (2009) surround the federal channel at the Port of Miami, and include the nearshore ridge complex, both north and south of the channel, Inner Reef north and south, and Outer Reef north and south (Fig. 1). The Inner Reef north ${ }^{1}$ is composed of two reef habitat types, including a Ridge-shallow (western portion) and Linear Reef (eastern portion). The current direction in the outer sections is dominated by the Florida Current with strong north-northeasterly flows, but the flow environment is complex with common current reversals and multiscale vortices capable of transporting suspended material in complex patterns (Martinez-Pedraja et al., 2004; McArthur et al., 2006).

The purpose of the Port of Miami expansion dredging project was to provide improved navigation and safety for larger vessels, including post-Panamax class ships. An Environmental

\footnotetext{
${ }^{1}$ Walker (2009) refers to this coral reef feature as Inner Reef. This portion of the Florida Reef Tract lacks a Middle Reef, and USACE reports often misidentify the Inner Reef as Middle Reef or Reef 2.
} 
86 Impact Statement (EIS) prepared by the Army Corps of Engineers (USACE) concluded the 87 dredging would result in 13,355 $\mathrm{m}^{2}$ (3.3 acres) of direct impacts (i.e. reef that was ground up and 88 permanently removed) to Outer Reef north and Outer Reef south. The EIS concluded impacts 89 may also include the resuspension and deposition of sediments on nearby coral reef assemblages, 90 but the area of anticipated sedimentation impact was not quantified (USACE, 2004). Nine years 91 later, the Port of Miami entrance channel expansion dredging project was implemented during a 92 17-month period between November 20, 2013, and March 16, 2015 (Suppl Fig. 1). Additional 93 maintenance dredging also occurred in the inner-harbor and federal channel, prior to and after 94 the expansion dredging. A reported 4.39 million $\mathrm{m}^{3}$ of material was dredged (C.J. McArthur, US 95 Environmental Protection Agency Region 4, pers. comm. Sept. 2016) via pipeline, backhoe, and 96 clamshell dredges and deposited to a permitted offshore disposal site $2.4 \mathrm{~km}$ east-southeast of the 97 project site in 120-240 m depth (EPA, 1995).

A permit ${ }^{2}$ was issued in 2012 to the USACE by the Florida Department of Environmental 99 Protection and included conditions for biological monitoring areas adjacent to the channel along each of six coral reef or hardbottom features (north and south of the channel in the Outer Reef, Inner Reef, and Nearshore Ridge; Fig. 1). All project-required monitoring stations were located within $50 \mathrm{~m}$ north and south of the channel (channel-side) in addition to reference areas located between 1.2 and $9.3 \mathrm{~km}$ from the channel (Fig. 1). The two baseline surveys were conducted in August 2010 (USACE, 2011) and October 23 through December 30, $2013^{3}$ (USACE, 2014). While the former baseline assessment included stations up to $450 \mathrm{~m}$ north of the channel on the Inner Reef north, the baseline surveys from 2013, during-dredging, and post-construction monitoring included only potential impact locations within $50 \mathrm{~m}$ of the channel.

Barnes et al. (2015) undertook an independent remote sensing analysis partitioning natural drivers of sediment plumes near the Port of Miami channel, such as storms, wind or runoff events, from dredging-associated sediment plumes. They determined that sediment 111 plumes detectable from satellite imagery during the dredging period were of 5x greater extent 112 (127-228 $\mathrm{km}^{2}$ during dredging compared to $18-46 \mathrm{~km}^{2}$ under normal conditions) and 23-84\%

\footnotetext{
${ }^{2}$ Florida Department of Environmental Protection Permit \#0305721-001-BI; ftp://ftp.dep.state.fl.us/pub/ENVPRMT/dade/issued/0305721_Miami_Harbor_Phase_III_Federal_Dredging/001BI/Final\%20Order/Miami\%20Harbor\%20Final\%20Örder\%20052212.pdf

${ }^{3} \mathrm{Up}$ to 40 days after the expansion dredging began.
} 
113 greater frequency than a baseline period prior to the start of dredging. This study also 114 documented the greatest frequency and intensity of dredging-associated sediment plumes over 115 the Inner Reef north reef sector. For this reason, we focused post-hoc sediment impact 116 assessment effort in this reef sector, recognizing that additional reef area was likely impacted in 117 the other sectors, with perhaps lesser intensity over a smaller extent.

118 The purpose of the current study was to better understand the sedimentation impacts that 119 occurred in the coral reef environment surrounding Port of Miami, to distinguish those impacts 120 from other regional events or disturbances, and provide supplemental information on impact 121 assessment to inform discussions on compensatory mitigation requirements. This paper reports 122 results from post-hoc field sampling focused on coral condition and standing sediment on reef 123 substrates. Sampling was conducted at five sedimentation assessment locations within the Inner 124 Reef north sector. Parallel sampling was conducted in the associated reference area, chosen and 125 followed as part of the compliance monitoring program, approximately $9 \mathrm{~km}$ north of the 126 channel and composed of similar reef habitat types (Fig. 1). In addition, analyses of 127 photographic time series of individual tagged coral colonies within channel-side and reference 128 locations throughout the project provide a Before/After comparison for coral status over the 129 project duration. Given the post-hoc nature of this analysis, we emphasized persistent effects, 130 namely coral mortality or partial mortality related to sedimentation and persistent sediment 131 presence in the reef environment. This conservative assessment does not address additional 132 physiological stress and/or more temporary effect pathways likely also invoked by project 133 associated turbidity and light attenuation (Jones et al., 2016) because post-hoc analysis using 134 available data was not possible.

\subsection{Methods}

\section{$137 \quad 2.1 \quad$ Post-hoc field sampling}

In December 2015, field sampling was conducted to quantify coral condition and 139 standing sediment on reef substrates at locations spanning increasing distance from the channel 140 in the Inner Reef north sector, in addition to the reference location (all 8-10 m depth; Fig. 1;

141 Suppl Fig. 1). These 'sediment assessment' locations were spaced at 100, 200, 300, 500 and 700 
$142 \mathrm{~m}$ from the channel. At each distance except $700 \mathrm{~m}$, transects were evenly distributed in both 143 Ridge-shallow (RR) and Linear Reef (LR) habitat types. At the $700 \mathrm{~m}$ distance, only the Linear 144 Reef habitat was assessed due to dive-time limitations. The reference location also included 145 transects sampled within both Ridge-shallow and Linear Reef habitat. The project reference 146 reefs were designated in a permit as part of the required compliance monitoring and were at least $1470.8 \mathrm{~km}$ away from the channel (with the Inner Reef North reference sites located $9.3 \mathrm{~km}$ to the 148 north). This distance was expected to be far enough away to prevent confounding effects from 149 background channel turbidity, sedimentation, and effects from the commercial anchorage. The 150 reference reefs were examined by divers and verified as representative of the intended habitat 151 type (USACE, 2010).

152 153 154 155 156 157 158 159 160 161 162 163 164 165 166 167 168 169 170
Using Google Earth Pro, specific dive sites for each sediment assessment location were randomly selected to be at or near the 100-m interval mark and include a dive site in both Ridgeshallow and Linear Reef habitat type. Exceptions were three dive sites (100-RR, 200-RR, and $300-R R)$ that were selected to correspond with dive sites surveyed in a pre-construction assessment the USACE completed in 2010. Overall, this results in five sedimentation assessment locations $(100,200,300,500$, and $700 \mathrm{~m}$ north of the channel), two dive sites per location - one in the Ridge-shallow and the other in the Linear Reef - with the exception of 700 $\mathrm{m}$, where only the Linear Reef was surveyed. A temporary marker buoy was deployed from the boat at the pre-determined coordinates. At each dive site, two 50-m long transects were run in opposite directions from the buoy and sampled at 1.0-m intervals (50 point samples per transect, two transects per site). Observers recorded the occurrence of standing sediment along the lineintercept transects, where present, in two categories. 'Sediment-over-hardbottom' (SOHB) was designated if there was a visible accumulation of sediment. For example, algal turfs normally have some sediment embedded within them, but if the turfs were engulfed by sediment, this would be labelled as SOHB. If the sediment was qualitatively observed to be deeper (estimated $>4.0 \mathrm{~cm}$ ), it was labelled as "deep sediment over hardbottom" (DSOHB). In addition, at every $5.0 \mathrm{~m}$ along each transect, the depth of the sediment $(\mathrm{cm})$ over hardbottom was measured with a ruler and the deepest of several measurements within one meter of the sample point was recorded. 
Six $10 \mathrm{~m}^{2}$ belt transects were also sampled along or parallel (within $10 \mathrm{~m}$ distance) with

172 the two line-intercept transects at each dive site to quantify the condition of coral colonies within 173 each area. Each scleractinian colony was recorded by species and condition; namely if the coral 174 displayed recent partial mortality (i.e., minimally encrusted skeleton in which individual calyces 175 were still discernable, Lirman et al., 2014), sediment present on live coral tissue (sediment 176 accumulation), active disease (distinct white skeleton progressing across the colony), bleaching, 177 "halo" mortality, or healthy if there were no noticeable signs of stress present. A "halo" refers to 178 a pattern of partial colony mortality in which a concentric ring of dead coral skeleton occurs at 179 the base of the coral colony as results from prior burial of the colony edges (Suppl Fig. 2A-C).

180 One-way ANOVAs followed by post-hoc tests between the assessment and reference 181 locations were used to determine statistically significant differences in each survey parameter. 182 For each of six parameters, (\% cover SOHB, \% cover DSOHB, sediment depth, and prevalences 183 of recent partial mortality, 'halo' partial mortality, and sediment accumulation), preliminary oneway ANOVAs (on ranks, due to violation of parametric assumptions) showed no significant differences between the two habitat types (p-values ranging from 0.134 to 0.975 among the six parameters). Thus, transects of both habitat types were pooled at each location (i.e. distance from channel or reference) to increase replication and power to detect differences among the locations via one-way ANOVAs (on ranks when parametric assumptions were violated).

\section{Before/After analysis of coral status, qualitative and quantitative}

Public records of time series photographs of tagged coral colonies taken as part of the compliance monitoring were obtained from the USACE. Tagged colonies were distributed in 193 both the Ridge-shallow and Linear Reef habitat types at the channel-side and the reference $(\sim 9.3$ 194 km north; Fig. 1) locations which had been designated for the permit monitoring. The colonies 195 tagged at each location were of mixed species composition according to what was present, but included Porites astreoides, Solenastrea bournoni, Pseudodiploria strigosa, Stephanocoenia intersepta, Meandrina meandrites, Siderastrea siderea, and Dichocoenia stokesii. Photographs were taken at irregular intervals between a four-week pre-construction phase ${ }^{4}$ (October November 2013) and a four-week post-construction phase (July 2015). Intervals between

${ }^{4}$ A portion of the pre-construction phase overlapped the onset of expansion dredging (Suppl Fig 1) 
200 images ranged from 1-121 (mean 14-18) days for the channel-side colonies and from 1-145 201 (mean 12-13) days at the reference site. The frequency of images varied according to permit 202 requirements; photographs were to be taken at greater frequency when dredging was occurring in 203 close proximity $(<750 \mathrm{~m})$ to the monitoring site. We thus made the conservative assumption 204 that long intervals between photos corresponded to times when dredging activities were 205 206 207 208 relatively distant and less influential, and that relevant instances of sediment interaction with the colonies are appropriately captured in the available time series for each colony.

The time series of each colony was examined and the temporal sequence of conditions affecting each colony was noted. Specifically, the presence of sediment accumulation on live tissue, partial sediment burial generally of colony edges, complete colony burial by sediment, the presence of active White Plague disease signs (i.e. bright white exposed skeleton along colony 212 skeleton), and 'sudden death' (the complete mortality of a colony between sequential photos in 213 the time series, presumably attributable to disease, though no active disease signs were 214 observable) were recorded in sequence. We included 'sudden death' in a category of disease 215 impact given consistency with described patterns of mortality (i.e. complete colony mortality 216 over a period of weeks) associated with a regional outbreak of 'White Plague' disease affecting most species of mounding corals during this time frame (Precht et al., 2016), a lack of other 218 known disturbances such as storms, and the presumption that the longer interval of images during which most of the 'sudden death' occurred (winter 2014-2015) was during a period when dredging activities were distant according to permit requirements (hence transient sediment burial unlikely). The potential effect of sediment stress on susceptibility was examined by estimating the risk of subsequent disease and/or death in a group of colonies which had previously experienced partial sediment burial compared to the remaining colonies which had not shown partial burial in the time series photos.

From this same set of time-series photographs, the live tissue area was quantified from the best-matched photo (angle and orientation) of each colony from the pre-construction and from the post-construction phase (generally four weekly photos in each phase) using the software 228 CPCe (Kohler \& Gill, 2006). Each photograph was calibrated using a scale bar with $5-\mathrm{cm}$ increments included in each image, and then the area $\left(\mathrm{cm}^{2}\right)$ was calculated by outlining the live tissue area for each colony. Proportional change in live tissue area was calculated for each 
231 colony (i.e. (post-pre) / pre)). Colonies which went missing prior to the post-construction phase 232 were excluded from this analysis. The colonies from the two habitat types in each location were 233 pooled and the change in colony area between locations was compared by a Mann-Whitney U234 test.

235

$236 \quad 3.0 \quad$ Results

\section{$237 \quad 3.1 \quad$ Post-hoc field sampling}

The mean percent cover of reef substrate characterized as "sediment over hardbottom" (SOHB) and "deep sediment over hardbottom" (DSOHB) was higher along the Inner Reef north transects (incorporating both Ridge-shallow and Linear Reef habitat), than the reference location transects (within the same habitat strata; Fig. 2A). The mean percent cover of SOHB was 17.5 to

$24236.0 x$ higher at Inner Reef north locations, when compared to reference location (Fig. 2A), 243 representing significant differences between each Inner Reef north location and the reference 244 (One- way ANOVA p=0.002 followed by post-hoc Holm-Sidak comparisons of each location 245 with the reference at $\mathrm{p}<0.05)$. At the reference location, $1 \%$ of the survey points exhibited reef 246 substrate characterized as SOHB. The mean percent cover of DSOHB showed significant 247 variation among sampled locations (one-way ANOVA on ranks, $\mathrm{p}=0.045$ ), ranging from 0.8 to $24810.8 \%$ at distances 100, 200, 500, and $700 \mathrm{~m}$ from the channel (Fig. 2A), compared to no 249 DSOHB recorded at the reference location nor the location $300 \mathrm{~m}$ north of the channel. However, statistical power was not adequate to discern significant differences for DSOHB 251 among locations.

The mean depth of sediment was significantly higher, ranging from 2.7 to $10.0 \mathrm{x}$ higher, at Inner Reef north locations (Fig. 2B), compared to that measured at the reference location (oneway ANOVA on ranks $\mathrm{p}=0.001$ followed by Dunn's post-hoc comparisons with reference). Specifically, along the transects located $200 \mathrm{~m}$ north of the channel, the mean sediment depth was $3.0 \mathrm{~cm}$ compared to $0.3 \mathrm{~cm}$ at the reference location (Fig. 2B-D). mortality at sediment assessment locations when compared to reference (Fig. 3; one-way ANOVA on ranks $\mathrm{p}=0.009$ ). Specifically, the 100,300 , and $700 \mathrm{~m}$ locations were significantly 
260

261

262

263

264

265

266

267

268

269

270

271

272

273

274

275

276

277

278

279

280

281

282

283

284

285

286

287

288

289

different than the reference (Dunns' post-hoc comparisons with reference, $p<0.05$ ). The occurrence of sediment accumulation (SA) on live coral tissue ranged from 4.8 to $21.3 \mathrm{x}$ higher at sedimentation assessment locations when compared to the reference location with the $100 \mathrm{~m}$ and $200 \mathrm{~m}$ locations being statistically higher (SA; one-way ANOVA on ranks $\mathrm{p}=0.002$ followed by Dunn's post-hoc comparisons with reference; Fig. 3). Sediment halos (mortality at the base of colonies due to elevated levels of sedimentation) on scleractinian corals ranged from 3 to $26 \mathrm{x}$ more frequent at sedimentation assessment locations when compared to the reference location with the $200 \mathrm{~m}$ and $300 \mathrm{~m}$ locations being significantly higher (Fig. 3; one-way ANOVA on ranks $p=0.011$ followed by Dunn's post-hoc comparisons with reference).

\subsection{Before/After analysis of coral status}

When the sequence of sediment and disease-related conditions are examined across all colonies, only minor sediment presence (e.g., Fig. 4-B) was observed on coral tissues (12 of 52 channel-side and 4 of 58 reference colonies) prior to June 2014. Major sediment accumulation including complete burial and several centimeter sediment berm (seemingly from colony expulsion of sediments, Fig. 4-D) and the subsequent burial of colony edges was observed starting in early June 2014 (half of channel-side colonies compared to 1 of 58 reference colonies; Suppl Fig. 1). Bleaching was observed primarily in August - November 2014 (Fig. 4-G; Suppl Fig. 1) with most of the colonies recovering (Fig. 4-H). Most colonies of Porites astreoides, which occurred only at the reference reef, also were bleached in July 2015 at the end of the time series. The predominance of active disease signs and rapid complete colony mortality among channel-side colonies occurred between late November 2014 and late February 2015. However, most disease and rapid colony mortality among reference reef colonies occurred later (FebruaryJuly 2015; Suppl Fig. 1).

Six channel-side colonies (11.5\%) displayed complete or almost complete colony mortality directly associated with sediment burial (i.e. directly following in time and tissue regression over similar footprint as previously buried, Suppl Fig. 3). Although one reference colony appeared to experience a minor degree of partial sediment burial of its edges, it manifested only modest partial mortality (Suppl Fig. 3C). The occurrence of disease and complete colony mortality for reference colonies was less than half that observed for channel- 
290 side colonies (Table 1), although disease occurrence was similar between channel-side colonies 291 that were observed with substantive partial burial (38\%) versus those that were not (34\%).

292 The tagged colonies at the channel-side location $(n=55)$, without regard to particular 293 conditions or attributions of coral loss, showed over 4x greater tissue loss on average than the 294 reference colonies ( $\mathrm{n}=58$, Fig. 5). This includes 17/55 (31\%) channel-side colonies versus 6/58 295 (10\%) reference colonies which suffered complete colony mortality. Meanwhile, 48\% of 296 reference colonies displayed positive growth over the course of the project, compared with only $29718 \%$ of channel-side colonies.

298

299

\subsection{Discussion}

300

A severe warm thermal stress (Eakin et al., 2016; Manzello, 2015) and coral bleaching

301

302

303

304

305

306

307

308

309

310

311

312

313

314

315

316

317

318 event affected south Florida coral reefs beginning in autumn 2014 (M. W. Miller, pers. obs. Sept. 2014; also documented in regional bleaching surveys as 30-55\% prevalence of bleaching in the sub-regions spanning Miami-Dade and Broward county; data available from Florida Reef Resilience Program at http://frrp.org/temp/JCDM3VBD/CoralDiseaseBySubregion.html; Suppl Fig. 1). As often occurs (Muller et al., 2008; Miller et al., 2009), the coral bleaching event was followed by severe but patchy coral disease outbreaks and mortality which were reported anecdotally throughout the region starting in winter 2014-2015 (Suppl Fig. 1). Precht et al. (2016) provide documentation of the origin, high lethality, and spread of this severe disease outbreak. These authors report the origination of this regional outbreak at the Inner Reef south reference site (referred to as 'Virginia Key', Fig. 1, located $\sim 1.2$ to $1.4 \mathrm{~km}$ south of the channel) in Sept. 2014 and the propagation of the outbreak both to the north and, more slowly, to the south.

13 Both bleaching and disease are documented in the time series observations of corals in both the Inner Reef north channel-side and reference populations (Fig. 4 and Suppl Fig. 3C) examined in the present study. Despite these coincident disturbances, analysis of tagged coral colony condition during the course of the dredging project shows significant and large effects in terms of more severe coral tissue loss (almost 5x) and increased risk of disease and death (> double) in the immediate vicinity of the dredged channel, in comparison with project-chosen 
319 reference reef. The permit-mandated monitoring plan did not, however, incorporate spatial 320 coverage of potentially impacted reef areas farther than $50 \mathrm{~m}$ from the channel that would aid in 321 determining the spatial extent of impact. We implemented the post-hoc sampling (i.e. $\sim 8$ mos 322 after dredging was completed) to partially address this gap. Although the determination of causes of coral mortality or partial mortality is always problematic, we compared the prevalence of several coral conditions and the persistent levels of standing sediment on reef substrates at a gradient of potential impact locations with the reference location to aid in delineation of the extent of sedimentation impact. and the reference location in terms of standing sediment and coral condition. Using the most objective measures such as sediment depth (almost 10x at the $200 \mathrm{~m}$ location) and prevalence of recent partial mortality ( $\sim$ double across all assessment locations), significant contrast is evident with the reference location. This pattern also is consistent with the less-objective or ephemeral parameters in our survey, such as the attribution of partial mortality patterns as 'halos' or the presence of sediment on live coral tissue. Unfortunately, there are no directly comparable baseline data for these parameters, raising a potential concern that high sediment impact, relative to the reference area, may be characteristic of a reef area adjacent to a high-traffic channel, rather than a direct effect of dredging. Baseline sampling was conducted by USACE at a gradient of sites out to $450 \mathrm{~m}$ in the Inner Reef North sector in 2010 and recorded a binary score (yes/no) for the presence of an unspecified 'sedimentation' condition and the overall prevalence of coral partial mortality (not specified whether recent or not). The 'sedimentation' score was reported as 'yes' at all sampled sites except the Inner Reef North site at 200 m where a 'no' was recorded for 'sedimentation'. The dive site for one of the two sampled in the current study at $200 \mathrm{~m}$ distance

342 (200-RR, Suppl Table 1) was overlain with the 2010 transect location (as described in Methods) 343 and showed $63 \%$ cover of SOHB and a mean sediment depth of $1.7 \mathrm{~cm}$, apparently a very 344 different condition than the absence of 'sedimentation' reported in 2010. Similarly, in 2010, the 345 prevalence of coral partial mortality was reported as 3.1\% and showed no significant relationship 346 with distance from the channel (USACE, 2011). Our survey results record evidence of the

347 severe impacts of regional coral stressors, such as thermal stress and disease in that the 348 prevalence of recent partial mortality for reference area corals was $7 \mathrm{x}$ higher $(21 \pm 3.5 \%$, mean \pm 349 1 SE) than the 2010 baseline assessment; however, the locations in the vicinity of the channel 
350 (up to $700 \mathrm{~m}$ distant) had values double those at the reference location $(44 \pm 3.4 \%$, mean $\pm 1 \mathrm{SE})$.

351 This pattern is also consistent with the reported results of Pollock et al. (2014) showing that

352 extended exposure to dredging project-related sediment plumes was a significant driver of

353 increased occurrence of compromised conditions of reef corals.

354

355

356

357

358

359

360

361

362

363

364

365

366

367

368

369

370

371

372

373

374

375

376

377

378

379

Neither the dredging process nor the Port of Miami entrance channel environment was conducive to a simple sedimentation gradient leading away from the channel and into the coral reef habitat. While the material dredged from the federal channel was predominantly limestone and sand below a thin layer of silt, the proportion of silt within material from the inner harbor was generally higher than from the entrance channel. Three types of dredges (clamshell, hopper, and pipeline) operated at various times and locations, and the amount of sediment suspended from these dredges can differ substantially under normal operation (McLellan et al., 1989). In addition, the pipeline dredges occasionally used a process known as "roller chopping" (punching the substrate with the cutterhead to pre-treat and fracture rocky substrate) with the suction deactivated. A spider barge staged at various locations along the outer entrance channel collected dredged material from the pipeline dredges and distributed the material to hopper barges for transport to the ocean disposal site. The permit did not set controls for the overflow of sediment-laden effluent from this process, and the overflow of sediments may have been substantial and variable. Likely additional sources of sedimentation from dredging operations include the disposal doors in the hopper barges not sealing shut properly leading to leakage from the barges. Given the differences in sediment characteristics and the manner and rate of sediment influx to the water column coupled with the varying oceanographic conditions along the $8.9 \mathrm{~km}$ length of the project (including inner harbor work) during the many months of dredging, the lack of a simple linear sedimentation or impact gradient leading from the channel is not surprising.

While sediment movement and deposition is a normal process in a coral reef ecosystem, offshore coral reefs are not capable of developing or sustaining ecological functions when substrates are covered by sediment over prolonged periods. The presence of deep sediment pockets within patchy reef habitats may also be a normal reef habitat feature. However, the presence of emergent sessile invertebrates (particularly soft corals, but also scleractinian corals and sponges, Fig. 2C-D, Suppl Fig. 2) in much of the area of observed deep sediment in our post- 
380 hoc surveys clearly indicated recent, extreme levels of accumulation and implies that additional, 381 uncountable scleractinian corals have been buried in these areas.

382

383

384

385

386

387

388

389

390

391

392

393

394

395

396

397

398

399

400

401

402

403

404

405

406

407 408

Although our replication was not adequate to discern habitat effects, the post-hoc survey results suggest differences in the severity of sedimentation impact between the habitat types. Most survey locations in the vicinity of the channel showed a trend for higher sediment cover and depth in the Linear Reef than the Ridge-shallow habitat (Suppl Table 1). The Linear Reef habitat $200 \mathrm{~m}$ north of the channel appears to have been the most severely impacted as this location had the highest cover $(43 \%)$ characterized as DSOHB $(4.0 \mathrm{~cm}$ or greater sediment over reef; Suppl Table 1), the highest measured maximum sediment depth $(10.0 \mathrm{~cm})$, and the highest prevalence of sediment halo (26\%; Suppl Table 1). It is possible the prevalences of recent mortality and sediment accumulation at Linear Reef (200 m) are underrepresented, when compared to other sites, because many low-lying scleractinian colonies have been completely buried.

Sedimentation on reefs can reduce coral recruitment, survival, and settlement of coral larvae (Fabricius et al. 2005, Erftemeijer et al., 2012b, Jones et al. 2015) and suppress colony growth (Bak, 1978). Our study focused on the reef sector which experienced the greatest duration of sediment plumes during the dredging project and relies heavily on the representativeness of the reference reef. This reference area was chosen to provide a representative comparison, comprising similar reef habitats, prior to initiation of dredging. Coral disease impacts can be very site specific (e.g., Miller et al., 2014), so a more spatially comprehensive quantitative analysis of coral disease effects both in potential impact areas and regionally would be beneficial. However, the increased prevalence of indicators of sedimentation stress and partial mortality, as well as persistent standing sediment on reef substrates at the Port of Miami sedimentation assessment areas (Fig. 2,3), all suggest the cumulative sedimentation was much greater across the assessment sites, when compared to the reference area, and mortality and loss of function of reef organisms resulted. When considering the findings of this study coupled with the findings of Barnes et al. (2015), sediment plumes and deposition via multiple pathways derived from dredging activities at Port of Miami are the most plausible drivers for this pattern. 
409

410

411

412

413

414

415

416

417

418

419

420

421

422

423

424

425

426

427

428

429

430

431

432

433

434

435

436

437

438

439

The implementation of seasonal shutdowns for dredging projects near coral reefs has largely been based on protecting corals during major spawning events. Unfavorable conditions during a coral spawning period could negate the entire reproductive output for the year (Harrison et al., 1984). Conducting dredging activities at appropriate times to avoid spawning periods would constitute a best management practice (Jones et al., 2015). Recommendations for reduced or halted dredging range from one week based on the known coral spawning period in Singapore (Ertemeijer et al., 2012b) to as many as five months per year based on known spawning periods in northern Western Australia (Baird et al., 2011). This best management practice could provide enhanced protection if shutdowns were also to coincide with increasingly predictable seasonal thermal stress events (van Hooidonk et al., 2014; Manzello, 2015) or less predictable cold water stress events. However, fixed predictable shutdowns are likely more practical especially if they are included in dredge contract bid specifications. In addition, feedback monitoring to effectively execute adaptive management may need to also include light attenuation and suspended sediment concentration. In Florida (USA) this practice has not been well-socialized in the regulatory context for coral protection with the exception of the Key West Harbor Dredging Project, where the contract provided for limited relocation of the dredge when coral health and sediment accumulation levels exceeded allowable thresholds (U.S. Navy, 2003).

Another port expansion at Port Everglades, located approximately $37 \mathrm{~km}$ north of Port of Miami, is on the horizon for southeast Florida. The construction plans at Port Everglades are similar in scale with USACE proposing to remove 4.21 million $\mathrm{m}^{3}$ of material. However, recent thermal stress and disease impacts have rendered the baseline reef condition as further impaired and less able to tolerate increments of 'standard' sedimentation stress associated with dredging activities in the past (e.g. Marzalek, 1982). The proposed Port Everglades monitoring plan is similar to that used for Port of Miami (USACE, 2015a), though expected to be modified to capture lessons learned in Miami. Notable improvements to the monitoring plan would include monitoring standing sediment depth, sediment-associated stressors (e.g., coral halo), light attenuation, suspended sediment concentration, near-realtime information feedback on monitoring outcomes, observations from other parties, and attending to regional disturbances such as warm-water and coral disease events. It is also crucial that the monitoring be undertaken at a spatial scale that can capture the indirect effect area (e.g., $3 \mathrm{~km}$ based on Fisher et al., 2015) with near realtime status/extent of sediment plumes via remote sensing (e.g., Barnes et al., 2015), 
440 and local oceanographic conditions as important guides. Time series analysis of permanently 441 marked corals could be used in concert with continuous water quality monitoring and sediment 442 depth measurements to make use of, and possibly contribute to, a rapidly evolving peer-reviewed 443 literature concerning thresholds for environmental impacts of dredging projects (e.g., Jones et al., 444 2016; Nelson et al., 2016; Fisher et al., 2015). Such an approach could provide an early 445 predictor of when and where sedimentation impacts are occurring to adaptively manage the 446 dredging. Inclusion of this type of monitoring could help in the development of no-work 447 windows, including when regional thermal events are ongoing. Even if no-work windows or 448 seasonal shutdowns are not implemented, monitoring thresholds could still be identified to serve 449 as a warning that coral impacts will exceed what was predicted under normal conditions. If 450 lessons learned from Port of Miami expansion are not memorialized, well-socialized, and fully 451 realized in the monitoring requirements developed for future projects, such as the Port 452 Everglades expansion, avoidable impacts may recur.

453

454

\subsection{Acknowledgements}

455 Field or logistical support was provided by J. Javech, J. Europe, R.Pausch, J. Blondeau, S. 456 Meehan and Callaway Marine Technologies. GIS support provided by K. Hanson.

457

458

459

460 461

462 463

464 465 466

467 468

\section{References}

Bak R. 1978. Lethal and sublethal effects of dredging on reef corals. Marine Pollution Bulletin 9:14-16.

Baird A, Blakeway D, Hurley T, Stoddart J. 2011. Seasonality of coral reproduction in the Dampier Archipelago, northern Western Australia. Marine Biology 158:275-285.

Barnes BB, Hu C, Kovach C, and Silverstein RN. 2015. Sediment plumes induced by the Port of Miami dredging: Analysis and interpretation using Landsat and MODIS data. Remote Sensing of Environment 170:328-339.

Dodge RE, and Vaisnys JR. 1977. Coral populations and growth patterns: responses to sedimentation and turbidity associated with dredging. Journal of Marine Research 35:715-730. 
469 Eakin M, Liu G, Gomez A, De la Cour J, Heron S, Skirving W, Geiger E, Tirak K, Strong A. 470 2016. Global Coral Bleaching 2014-2017? Status and Appeal for Observations. Reef Encounter $471 \quad 31: 20-26$.

472 Erftemeijer P, Riegl B, Hoeksema B, and Todd P. 2012a. Environmental impacts of dredging 473 and other sediment disturbances on corals: A review. Marine Pollution Bulletin 64:1737-1765.

474 Erftemeijer P, Hagedorn M, Laterveer M, Craggs J, Guest JR. 2012b. Effect of suspended

475 sediment on fertilization success in the scleractinian coral Pectinia lactuca. Journal of the Marine 476 Biological Association of the United Kingdom 92:741-745.

477 Fabricius KE. 2005. Effects of terrestrial runoff on the ecology of corals and coral reefs: review 478 and synthesis. Marine Pollution Bulletin 50:125-146.

479 Fisher R, Stark C, Ridd P, and Jones R. 2015. Spatial patterns in water quality changes during 480 dredging in tropical environments. PLoS ONE 10(12): e0143309.

481 doi:10.1371/journal.pone.0143309

482 Harrison P, Babcock R, Bull G, Oliver J, Wallace C, Willis B. 1984. Mass spawning in tropical 483 reef corals. Science 223:1186-1189.

484 Jones R, Ricardo GF, Negri AP. 2015. Effects of sediments on the reproductive cycles of corals. 485 Marine Pollution Bulletin 100:13-33.

486 Jones R, Bessell-Browne P, Fisher R, Klonowski W, and Slivkoff M. 2016. Assessing the 487 impacts of sediments from dredging on corals. Marine Pollution Bulletin 102:9-29.

488 Kohler KE, and Gill SM. 2006. Coral Point Count with Excel extensions (CPCe): A Visual Basic 489 program for the determination of coral and substrate coverage using random point count 490 methodology. Computers and Geosciences 32:1259-1269.

491 Lirman D, Formel N, Schopmeyer S, Ault J, Smith S, Gilliam D, and Riegl B. 2014. Percent 492 recent mortality (PRM) of stony corals as an ecological indicator of coral reef condition.

493 Ecological Indicators 44:120-127.

494 Manzello DP. 2015. Rapid recent warming of coral reefs in the Florida Keys. Scientific Reports 495 5:16762.

496 Martinez-Pedraja JJ, Shay LS, Cook T, and B. H. 2004. Technical Report: Very-High Frequency 497 Surface Current Measurement Along the Inshore Boundary of the Florida Current During NRL 498 2001. Rosenstiel School of Mar and Atmos Sci Tech Rept, RSMAS-2004-03. Miami FL:

499 University of Miami. p 29. Available from http://iwave.rsmas.miami.edu/wera/docs/nrl4.pdf 500 (accessed 13 Oct 2016).

501 Marzalek DS. 1982. Impact of dredging on a subtropical reef community, Southeast Florida, 502 USA, Proceedings of the 4th Int Coral Reefs Symp 1:147-154 
503 McArthur CJ, Stamates SJ, and Proni JR. 2006. Review of the real-time current monitoring 504 requirement for the Miami Ocean Dredged Material Disposal Site (1995-2000). NOAA

505 Technical Memorandum, OAR AOML-95. 21pp. Available from

506 http://www.aoml.noaa.gov/general/lib/TM/TM_OAR_AOML_95.pdf (accessed 13 Oct 2016)

507 McLellan, TN, . Havis RN Hayes DF, and Raymond GL. 1989. Field studies of sediment

508 resuspension characteristics of selected dredges. USACE Technical Report HL-89-9.

509 Environmental Laboratory, US Army Corps of Engineers, Vicksburg MS. 111 pp. Available

510 from http://acwc.sdp.sirsi.net/client/search/asset/1003509 (accessed 13 Oct 2016).

511 Miller J, Muller E, Rogers C, Waara R, Atkinson A, Whelan KRT, Patterson M, and Witcher B.

512 2009. Coral disease following massive bleaching in 2005 causes $60 \%$ decline in coral cover on

513 reefs in the US Virgin Islands. Coral Reefs 28:925-937.

514 Miller MW, Lohr KE, Cameron CM, Williams DE, and Peters EC. 2014. Disease dynamics and 515 potential mitigation among restored and wild staghorn coral, Acropora cervicornis. PeerJ 2:e541.

516 Muller EM, Rogers CS, Spitzack AS, and van Woesik R. 2008. Bleaching increases likelihood of 517 disease on Acropora palmata (Lamarck) in Hawksnest Bay, St John, US Virgin Islands. Coral 518 Reefs 27:191-195.

519 Nelson D, McManus J, Richmond R, King Jr.D, Gailani, J, Lackey T, and Bryant D. 2016.

520 Predicting dredging-associated effects to coral reefs in Apra Harbor, Guam - Part 2: Potential 521 coral effects. Journal of Environmental Management 168:111-122.

522 PIANC. 2010. Dredging and port construction around coral reefs. The World Association for 523 Waterborne Transport Infrastructure. Dredging and port construction around coral reefs, Report

524 108. 94pp. Available at http://www.unep-wcmc.org/resources-and-data/pianc-dredging-and-port525 construction-around-coral-reefs. (accessed 13 Oct 2016)

526 Pollock FJ, Lamb JB, Field SN, Heron SF, Schaffelke B, Shedrawi G, Bourne DG, and Willis

527 BL. 2014. Sediment and Turbidity Associated with Offshore Dredging Increase Coral Disease 528 Prevalence on Nearby Reefs. PLoS ONE 9:e102498.

529 Precht WF, Gintert BE, Robbart ML, Fura R, and van Woesik R. 2016. Unprecedented Disease530 Related Coral Mortality in Southeastern Florida. Scientific Reports 6:31374.

531 Rogers C. 1990. Responses of coral reefs and reef organisms to sedimentation. Marine Ecology 532 Progress Series 62:185-202.

533 U.S. Army Corps of Engineers, Jacksonville District. 2004. Final Environmental Impact 534 Statement for the Miami Harbor. 134pp, plus appendices. Available at 535 http://cdm16021.contentdm.oclc.org/cdm/ref/collection/p16021 coll7/id/2092. (accessed 13 Oct 536 2016) 
537 U.S. Army Corps of Engineers, Jacksonville District. 2010. Miami Harbor Hardbottom

538 Assessment Pilot Study and Quantitative Study Plan. Final technical memorandum prepared by

539 Dial Cordy and Associates. 225pp. Available at

540 http://data.nodc.noaa.gov/coris/library/NOAA/CRCP/other/non_crep_publications/Miami_Harbo

541 r_Hardbottom_Assessment_Pilot_Study_Quantitative_Study_Plan-Tech_Memo_Final_7-7-

54210 wFigsAppends.pdf. (accessed 13 Oct 2016)

543 U.S. Army Corps of Engineers. 2011. Miami Harbor Baseline Study. Prepared by Dial Cordy

544 and Associates Inc. 96 pp. Available at

545 http://data.nodc.noaa.gov/coris/library/NOAA/CRCP/other/non_crep_publications/Miami_quanti

546 tative FINAL_3-15-11_wFigs_Append.pdf. (accessed 13 Oct 2016)

547

548 U.S. Army Corps of Engineers. 2014. Miami Harbor Phase III Quantitative Baseline for Middle

549 and Outer Reef Benthic Communities. Prepared by Dial Cordy and Associates Inc. 322pp.

550 Available at

551 http://data.nodc.noaa.gov/coris/library/NOAA/CRCP/other/non crep publications/Miami Harbo

552 r_Middle_Outer_Reef_FINAL_4-16-14_REVISED_wFigs_Append.pdf. (accessed 13 Oct 2016)

553 U.S. Army Corps of Engineers, Jacksonville District. 2015a. Final Environmental Impact

554 Statement for the Port Everglades Harbor Navigation Study. 346pp, plus appendices. Available

555 at

556 http://www.saj.usace.army.mil/Portals/44/docs/Planning/EnvironmentalBranch/EnvironmentalD

557 ocs/PortEvergladesFinalRPT_01mainr.pdf. (accessed 13 Oct 2016)

558 U.S. Army Corps of Engineers, Jacksonville District. 2015b. Miami Harbor Phase III Federal

559 Channel Expansion Project Quantitative Post-Construction Middle and Outer Reef Benthic

560 Assessments. Prepared by Dial Cordy and Associates Inc. 156pp. Available at

561 http://data.nodc.noaa.gov/coris/library/NOAA/CRCP/other/non_crcp_publications/Miami_Harbo

562 r_Phase_III.pdf. (accessed 13 Oct 2016)

563 U.S. Environmental Protection Agency. 1995. Final Environmental Impact Statement for

564 Designation of an Ocean Dredged Material Disposal Site Located Offshore Miami, Florida. 417

565 pp. Available at

566 http://www.saj.usace.army.mil/Portals/44/docs/Planning/EnvironmentalBranch/EnvironmentalD

567 ocs/Miami\%20ODMDS\%20FEIS-NL.pdf. (accessed 13 Oct 2016)

568 U.S. Navy. 2003. Key West Harbor Dredging Monitoring and Mitigation Plan. Prepared by

569 Continental Shelf Associates, Inc. for the Department of the Navy Southern Division Naval

570 Facilities Engineering Command. 43 pp. Available at

571 http://data.nodc.noaa.gov/coris/library/NOAA/CRCP/other/non_crep_publications/Final_Mand

572 M_Plan_KWHD.pdf. (accessed 13 Oct 2016) 
573 van Hooidonk R, Maynard JA, Manzello D, and Planes S. 2014. Opposite latitudinal gradients in 574 projected ocean acidification and bleaching impacts on coral reefs. Global Change Biology $575 \quad 20: 103-112$. 
576 Table 1: Partitioning of tagged colonies that experienced substantial sediment burial (complete or 577 partial) and subsequent disease or death. Risk is calculated as the percent of colonies in each 578 category which manifest disease or death.

579

\begin{tabular}{|c|c|c|c|}
\hline GROUP & $\begin{array}{c}\text { SEDIMENT } \\
\text { INTERACTION }\end{array}$ & $\begin{array}{c}\text { SUBSEQUENT } \\
\text { DISEASE/DEATH }\end{array}$ & RISK \\
\hline \multirow[t]{4}{*}{$\begin{array}{c}\text { Channel-side } \\
52\end{array}$} & \multirow[t]{2}{*}{$\begin{array}{c}\text { Yes } \\
26\end{array}$} & $\begin{array}{c}\text { Yes } \\
10\end{array}$ & \multirow[t]{2}{*}{$38 \%$} \\
\hline & & $\begin{array}{c}\text { No } \\
16 \\
\end{array}$ & \\
\hline & \multirow[t]{2}{*}{$\begin{array}{l}\text { No } \\
26\end{array}$} & $\begin{array}{c}\text { Yes } \\
9\end{array}$ & \multirow[t]{2}{*}{$34 \%$} \\
\hline & & $\begin{array}{c}\text { No } \\
17 \\
\end{array}$ & \\
\hline \multirow{5}{*}{$\begin{array}{c}\text { Reference } \\
59\end{array}$} & \multirow{3}{*}{$\begin{array}{c}\text { Yes } \\
1\end{array}$} & Yes & \multirow[t]{3}{*}{$0 \%$} \\
\hline & & 0 & \\
\hline & & $\begin{array}{c}\text { No } \\
1\end{array}$ & \\
\hline & \multirow[t]{2}{*}{$\begin{array}{c}\text { No } \\
58\end{array}$} & $\begin{array}{c}\text { Yes } \\
9 \\
\end{array}$ & \multirow[t]{2}{*}{$15 \%$} \\
\hline & & $\begin{array}{l}\text { No } \\
49\end{array}$ & \\
\hline
\end{tabular}


582 Figure 1. Left, Port of Miami channel-side, sedimentation assessment and reference sites for all 583 reef habitat types. Yellow boxes indicate locations of additional project-associated channel-side 584 and reference sites for the Nearshore Ridge Complex, Outer Reef, and Inner Reef south that were 585 not addressed in the current study. Right upper inset, Inner Reef north (red) and Outer Reef 586 north (yellow; not addressed in the current study) reference sites, $9.3 \mathrm{~km}$ north of the channel. 587 Right lower inset, Port of Miami channel-side and sedimentation assessment sites for the Inner 588 Reef north. Red boxes indicate locations of channel-side and reference area tagged coral colonies 589 for Inner Reef north. Dots represent sedimentation assessment dive sites at 100, 200, 300, $500 \mathrm{~m}$ 590 north of the channel in each habitat (Ridge-shallow depicted by cross-hatch, Linear reef by 591 diagonal shading) of the Inner Reef, and 700 m north of the channel in the Inner Reef, Linear 592 Reef. The base layer is from December 2014 (Google Earth Pro) during active dredging close to

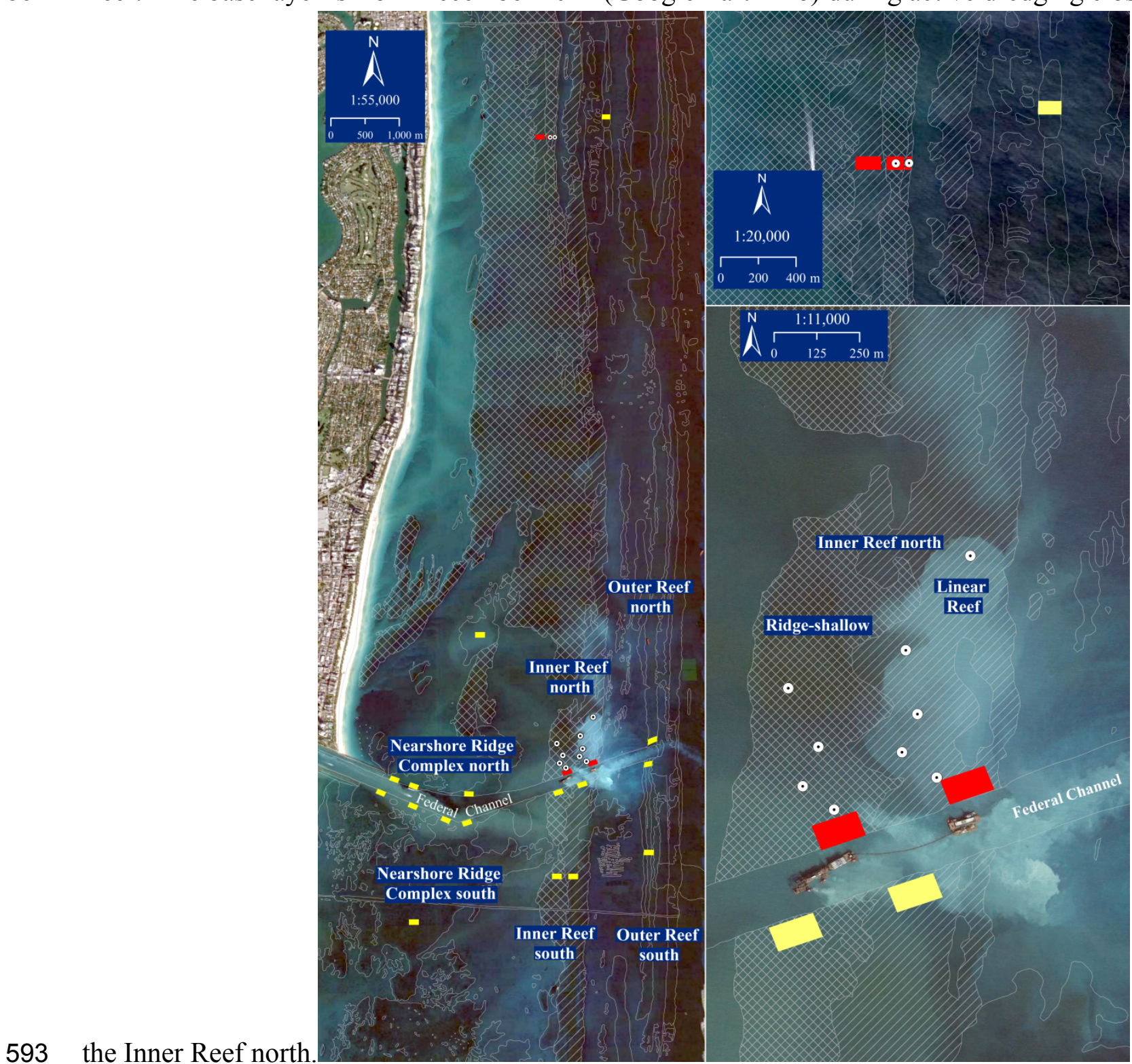


595 Figure 2: (A) Mean (+1 SE) percent cover of sediment over hardbottom (SOHB) and deep sediment over hardbottom (DSOHB; $>4 \mathrm{~cm}$ depth) along line point-intercept transects at sites of increasing distance from the channel and reference site. $\mathrm{N}=4$ transects for each, except $700 \mathrm{~m}$ where only two transects were sampled (hence no error bars are given). (B) Mean (+1 SE) depth of sediment at $0.5 \mathrm{~m}$ intervals along the same transects. Both habitat types were sampled at all sites except $700 \mathrm{~m}$ (LR only). Each of the sediment assessment locations had significantly higher SOHB cover and sediment depth than the reference area in post-hoc comparisons following oneway ANOVAs. (C-D) Illustration of expanse of deep sediment at the $200 \mathrm{~m}$ location showing 603

604 soft corals with several cm burial (photos taken 11 Dec $2015 ; 25.763852^{\circ} \mathrm{N}, 80.098928^{\circ} \mathrm{W}$ ).
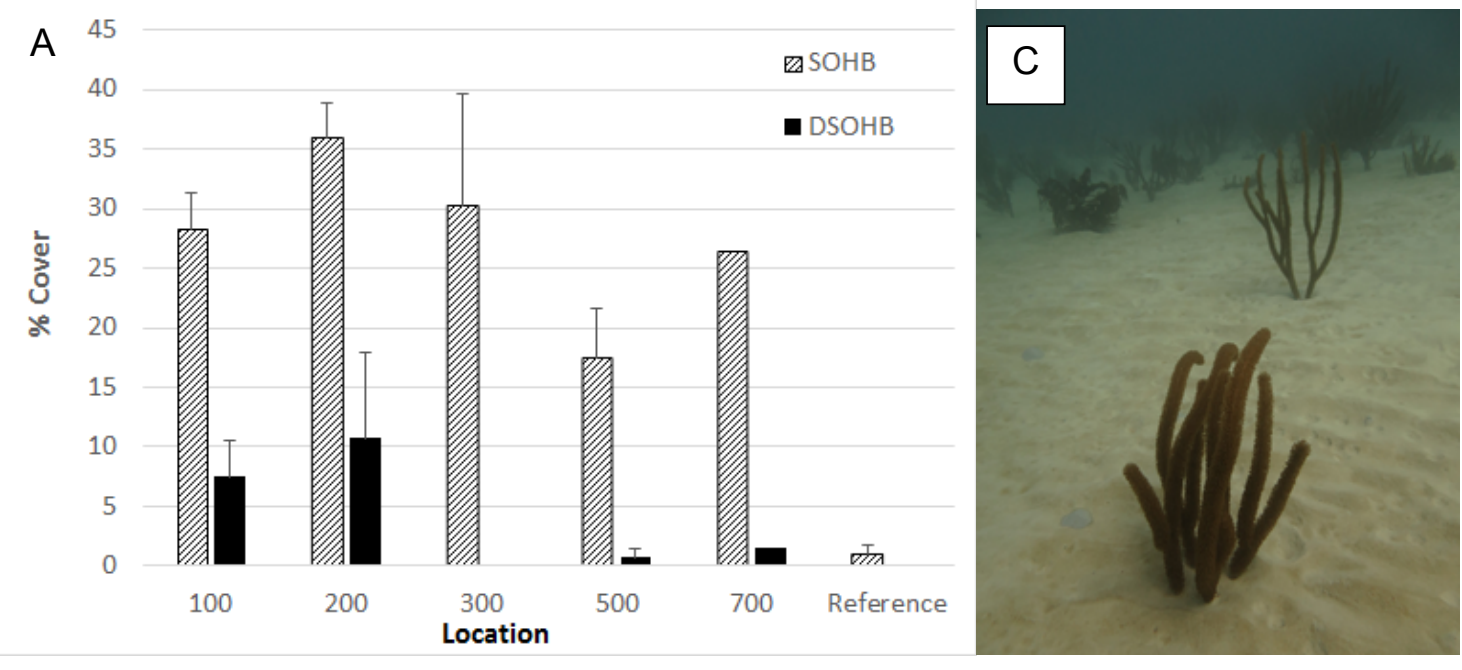

\section{B 4.0}

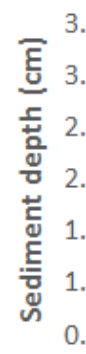

605
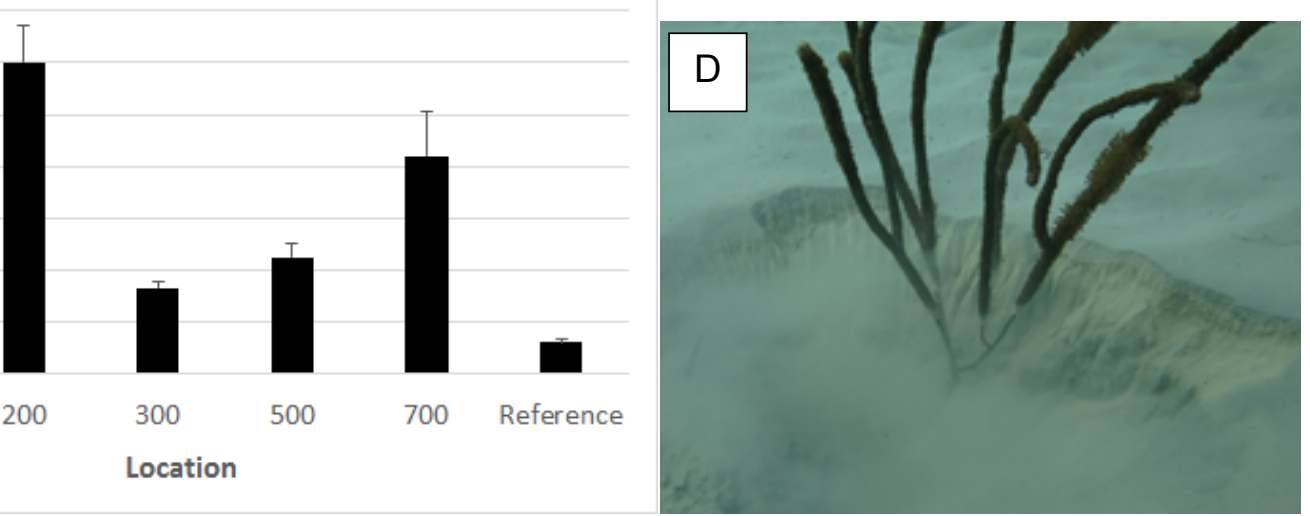

606

607

608

609

610 
611 Figure 3: The overall prevalence (mean $+1 \mathrm{SE}$ ) of colony conditions at sites spanning a gradient 612 of distance from the dredged channel $(100-700 \mathrm{~m})$ and the reference site. Habitat types are 613 pooled ( $\mathrm{n}=12$ transects per location) with exception of $700 \mathrm{~m}$ site (only Linear Reef habitat 614 sampled, $n=6$ transects) and $500 \mathrm{~m}$ and $300 \mathrm{~m}(\mathrm{n}=13$ transects per location, with the one 615 additional transect being in the Linear Reef habitat). Sed Accum = sediment presence on living 616 coral tissue; PmortRecent $=$ recent partial mortality among colonies (Lirman et al. 2014); Halos $617=$ distinct pattern of partial mortality (not necessarily recent) in which tissue loss manifests as an 618 outer concentric ring or partial ring which is consistent with that resulting from previous partial 619 burial of the colony (see Suppl Fig. 2 for illustration). Ref = Reference location.

620

621

622

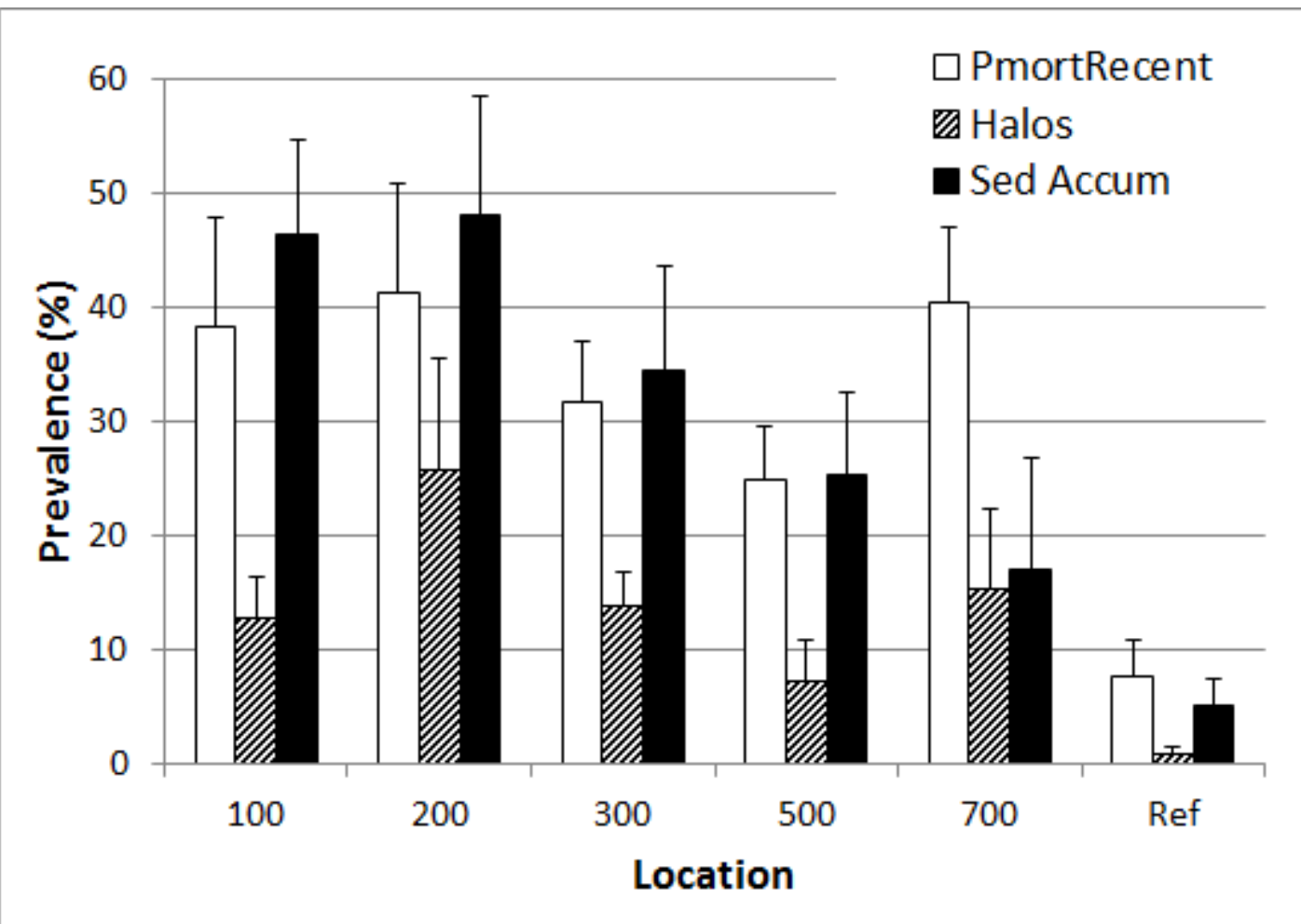

623

624

625 
626 Figure 4 : Intermittent time series photos for a Pseudodiploria strigosa colony (designated R2N1 627 T1 C2) illustrating different conditions including sediment accumulation (B, E), partial burial 628 (C), sediment 'berm' around coral margin (D), bleaching $(G)$, recovery $(H)$, and 'sudden death' 629 (I). Also note the degree of accumulated sediment on the surrounding reef substrate. This 630 colony was located in the Inner Reef north channel-side permit-monitoring site, within $30 \mathrm{~m}$ of 631 the channel. Dates given as Month/Day/Year. Additional illustrations given in Suppl Fig. 3.

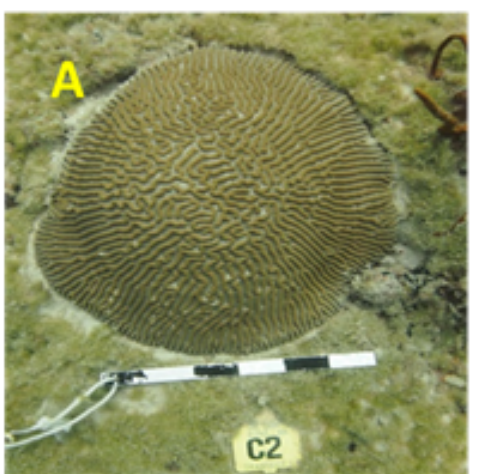

$10 / 21 / 13$

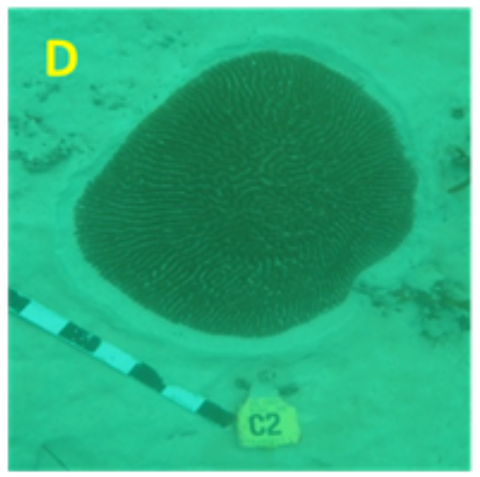

$6 / 22 / 14$

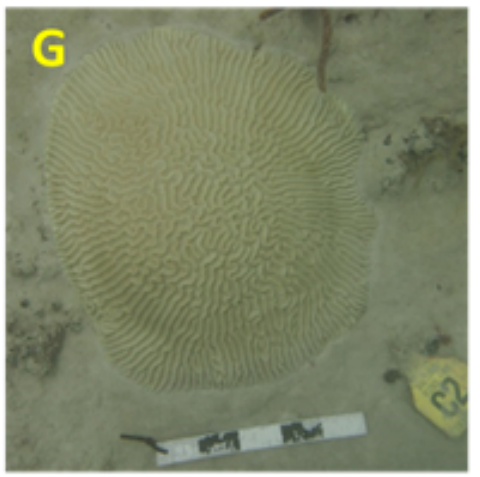

$9 / 14 / 14$

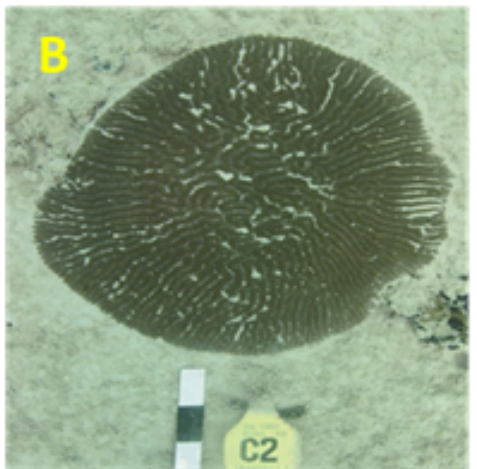

$4 / 25 / 14$

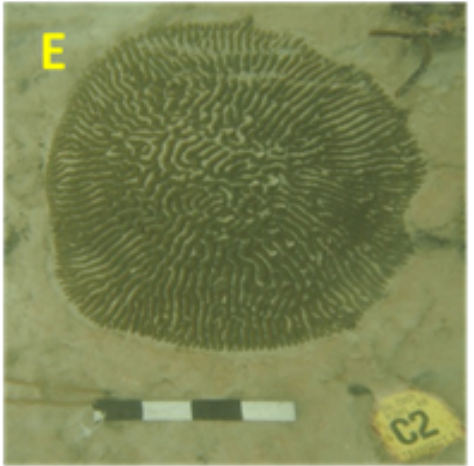

$7 / 17 / 14$

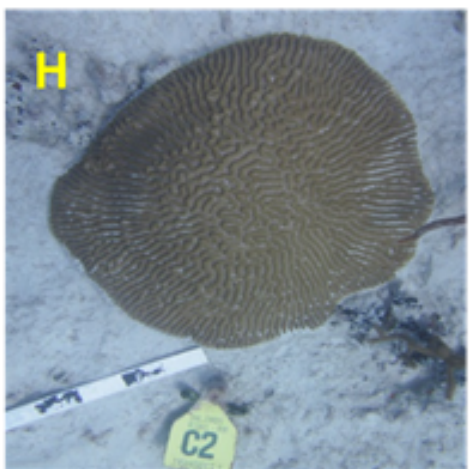

$11 / 13 / 14$

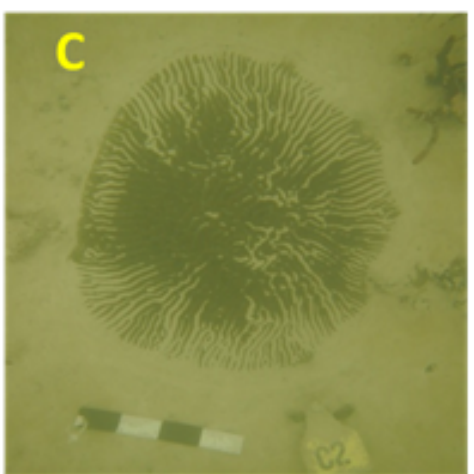

$6 / 16 / 14$

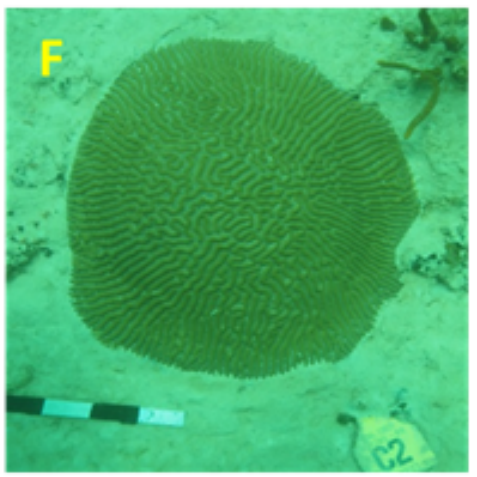

$8 / 21 / 14$

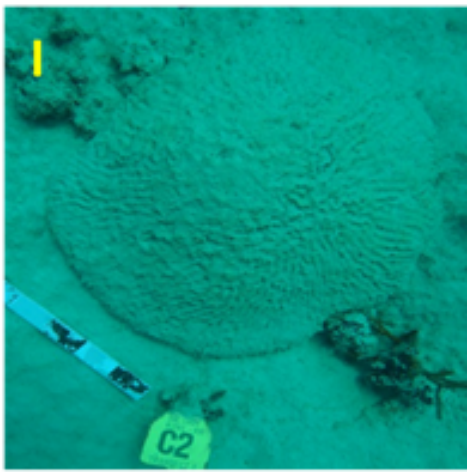

$2 / 25 / 15$ 
634 Figure 5: Proportional change in coral tissue area (mean \pm 1 SE) for tagged colonies between the 635 Baseline and Post-Construction period ( $\sim 18$ months). N=55 or 60 colonies (Channel-side, 636 Reference, respectively). Channel-side colonies lost significantly more tissue.

637

638

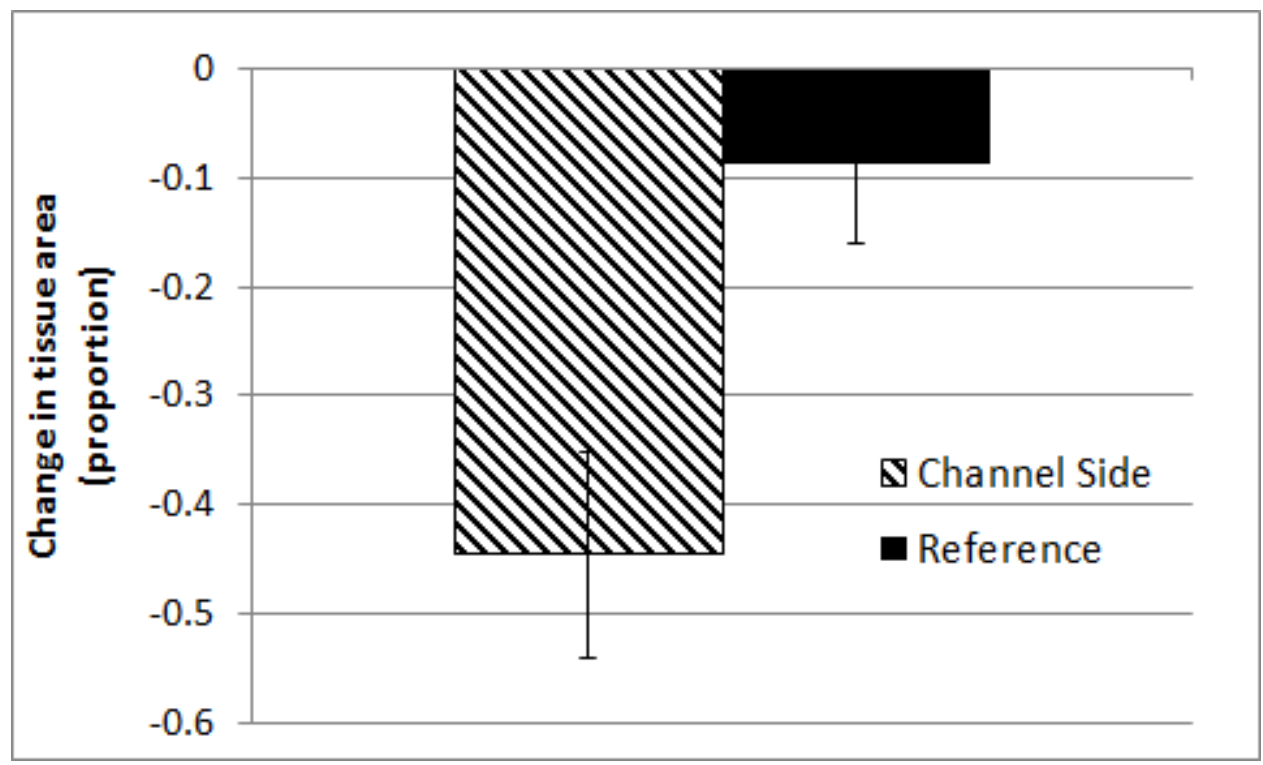

639

640

641

642

643

644

645 